\title{
STRATEGI PENGEMBANGAN USAHATANI SAYURAN DI KELURAHAN KALAMPANGAN KECAMATAN SABANGAU KOTA PALANGKA RAYA
}

\author{
Remi Marsinta Lingga ${ }^{1)}$, Abdul Mukti ${ }^{2)}$, dan Jhon Wardie ${ }^{2)}$
}

\begin{abstract}
This study aims to identify internal and external factors that affect the management of vegetable farming, development strategies, and priorities so that it is expected to be useful in developing the management of this farm. Qualitative data were compiled from informants consisting of selected key informants and local respondents selected randomly from local farmers. This data is analyzed descriptively and quantized by using SWOT method and by using QSPM (Quantitative Strategic Planning Matrix) matrix. The results showed that the development of vegetable farming is influenced by the availability of large enough land but less fertile / peat. The trend of market demand tends to increase but there are fewer local and external competitors; Strategy analysis through SWOT matrix resulted seven alternative strategies that is optimizing the potential of land owned by opening access road to vegetable farming area, and expanding vegetable planting area; follow technological developments in vegetable farming, especially organic vegetables, and develop business with the utilization of capital assistance; increase production and quality of crops; to make peatlands suitable for agricultural land and to minimize costs. Priority strategies that can be applied in the development of vegetable farming based on QSPM are: the means of production and agricultural tools available locally, the distance of the competitor's location with the vegetable market further, and the majority of the population work as farmers (no shortage of labor).
\end{abstract}

\section{Keywords : development strategy, SWOT method, QSPM}

\section{PENDAHULUAN}

\subsection{Latar Belakang dan Permasalahan}

Usahatani sayuran di Kelurahan Kalampangan paling berpotensi untuk dikembangkan di Kota Palangka Raya mengingat faktor alam yang sesuai untuk pertumbuhannya serta akses dan pemasarannya mendukung. Meskipun demikian, belum cukup menjamin perkembangan pesat akan terjadi. Berbagai faktor baik internal maupun eksternal sangat mempengaruhi perkembangan usahatani sayuran tersebut. Kondisi internal maupun eksternal usahatani sayuran di Kelurahan Kalampangan harus dipertimbangkan dalam pengambilan strategi pengembangan yang terbaik.

\subsection{Tujuan Penelitian}

Berdasarkan permasalahan di atas maka penelitian ini bertujuan untuk:

1. Mengidentifikasi faktor-faktor internal dan eksternal yang mempengaruhi pengembangan usahatani sayuran.

2. Merumuskan alternatif strategi yang memungkinkan untuk diterapkan dalam pengembangan usahatani sayuran.

3. Menentukan strategi prioritas yang dapat diterapkan untuk pengembangan usahatani sayuran.

\subsection{Manfaat Penelitian}

Dari hasil penelitian ini diharapkan bermanfaat bagi:

1. Petani, sebagai bahan informasi untuk memperbaiki pengelolaan usahanya.

2. Pemerintah, sebagai bahan pertimbangan dalam menyusun 
program yang terkait dengan pengembangan usahatani sayuran.

3. Kalangan akademisi, sebagai bahan informasi, bahan acuan serta bahan referensi bagi peneliti lain yang ingin mengkaji lebih lanjut dan yang memiliki ketertarikan untuk mengembangkan penelitian serupa.

\section{TINJAUAN PUSTAKA}

\subsection{Strategi Pengembangan Usahatani Sayuran dan Konsep SWOT}

Strategi adalah perencanaan induk komprehensif, yang menjelaskan bagaimana usaha akan mencapai semua tujuan yang telah ditetapkan berdasarkan misi yang telah ditentukan sebelumnya (Rangkuti, 2009). Beberapa definisi tentang strategi terdapat pada beberapa literatur, antara lain: Mintzberg (1993) menyatakan bahwa strategi adalah pola atau rencana yang mengintegrasikan sasaran utama, kebijakan, dan tindakan organisasi yang disusun menjadi satu kesatuan yang terpadu. David (2005) berpendapat bahwa strategi merepresentasikan tindakan yang akan diambil untuk mencapai tujuan jangka panjang. Secara umum dapat dikatakan bahwa strategi adalah cara untuk mencapai suatu tujuan dengan menggunakan sumber daya yang dimiliki dalam suatu kondisi lingkungan tertentu. Strategi itu sendiri memiliki arti bahwa semua kegiatan yang ada dalam lingkup perusahaan, termasuk di dalamnya pengalokasian sumberdaya yang dimiliki perusahaan. Sedangkan pengembangan juga berarti proses, cara, perbuatan mengembangkan (Kamus Besar Bahasa Indonesia, 1990). Berdasarkan pengertian di atas dapat disimpulkan bahwa strategi pengembangan adalah kunci keberhasilan dalam menanggapi perubahan lingkungan bisnis. Strategi memberikan kesatuan arah bagi semua anggota organisasi. Bila konsep strategi tidak jelas, maka keputusan yang diambil akan bersifat subyektif atau berdasarkan institusi belaka dan mengabaikan keputusan yang lain. Maka dari itu strategi dibutuhkan untuk penyusunan langkah ke depan dalam mencapai tujuan.

Soekartawi (2002) menyatakan bahwa usahatani pada hakekatnya adalah perusahaan, maka seorang petani atau produsen sebelum mengelola usahataninya akan mempertimbangkan antara biaya dan pendapatan, dengan cara mengalokasikan sumberdaya yang ada secara efektif dan efisien, guna memperoleh keuntungan yang tinggi pada waktu tertentu. Dikatakan efektif bila petani atau produsen dapat mengalokasikan sumberdaya yang mereka miliki dengan sebaik-baiknya, dan dikatakan efisien bila pemanfaatan sumberdaya tersebut menghasilkan keluaran (output) yang melebihi masukan (input). Menurut Astawan (2007), sayursayuran didefinisikan sebagai bagian dari tanaman yang umum dimakan untuk memenuhi kebutuhan gizi seseorang. Menurut Setyati (1989), sayuran memiliki ciri-ciri antara lain: 1) dipanen dan dimanfaatkan dalam keadaan segar atau hidup sehingga bersifat mudah rusak; 2) komponen utama mutu ditentukan oleh kandungan air bukan kandungan bahan kering seperti halnya tanaman agronomi, contohnya jagung dan tanaman perkebunan; 3) harga sayuran ditentukan oleh mutu atau kualitas bukan jumlahnya.

Menurut Rangkuti (2009), analisis SWOT adalah identifikasi berbagai faktor secara sistematis untuk merumuskan strategi perusahaan. Analisis ini didasarkan pada logika yang dapat memaksimalkan kekuatan (Strengths) dan peluang (Opportunities), namun secara bersamaan dapat meminimalkan kelemahan (Weakness) dan ancaman (Threats). Analisis SWOT membandingkan antara faktor eksternal peluang (Opportunities) dan ancaman (Threats) dengan faktor internal kekuatan (Strengths) dan kelemahan (Weakness). Secara ringkas analisis ini dapat dilihat pada gambar berikut: 


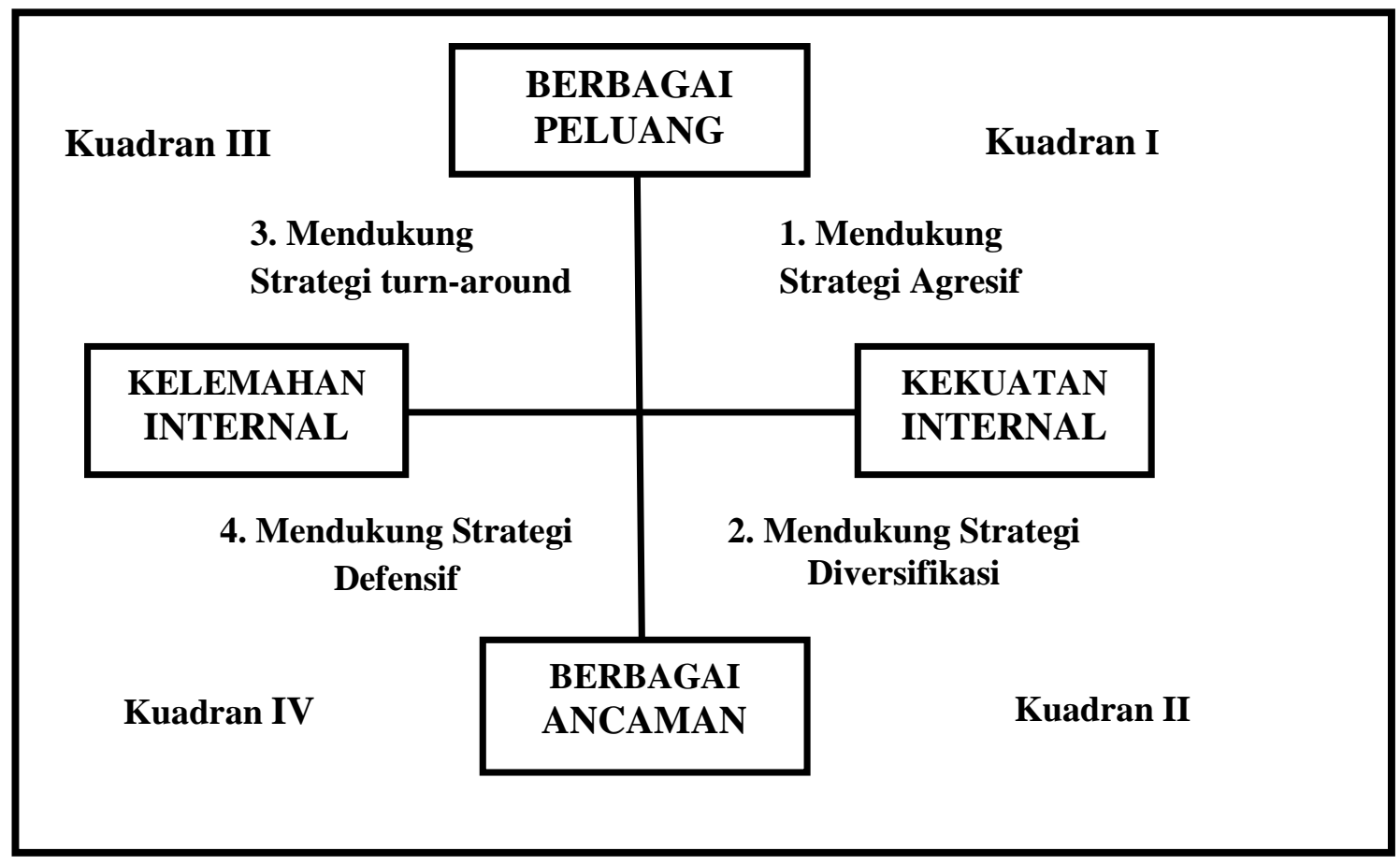

Sumber : Rangkuti, 2009

\section{Gambar 2.1 Analisis SWOT}

Berdasarkan gambar di atas dapat kita ketahui bahwa kuadran I merupakan situasi yang sangat menguntungkan. Perusahaan tersebut memiliki peluang dan kekuatan sehingga dapat memanfaatkan peluang yang ada. Strategi yang harus diterapkan dalam kondisi ini adalah mendukung kebijakan pertumbuhan yang agresif (growth oriented strategy). Dalam kuadran II meskipun menghadapi berbagai ancaman, perusahaan ini masih memiliki kekuatan dari segi internal.

Strategi yang harus diterapkan adalah menggunakan kekuatan untuk memanfaatkan peluang jangka panjang dengan cara strategi diversifikasi (produk/pasar). Kemudian di dalam kuadran III dijelaskan bahwa perusahaan menghadapi peluang pasar yang sangat besar, tetapi dilain pihak, ia menghadapi beberapa kendala/kelemahan internal. Kondisi bisnis pada kuadran III ini mirip dengan Qustion mark pada BCG Matrix. Fokus strategi perusahaan ini adalah meminimalkan masalah-masalah internal perusahaan sehingga dapat merebut peluang pasar yang lebih baik. Sedangkan di kuadran IV ini merupakan situasi yang tidak menguntungkan, perusahaan tersebut menghadapi berbagai ancaman dan kelemahan internal (Rangkuti, 2009)

\subsection{Tinjauan Penelitian Terdahulu}

Berdasarkan hasil penelitian Firmansyah (2016) yang berjudul "Strategi Pengembangan Usahatani Sayuran Organik Kelompok Tani Bangkit Merbabu di Kabupaten Semarang Provinsi Jawa Tengah" menunjukkan bahwa faktor internal yang menjadi kekuatan utama dalam pengembangan usahatani sayuran organik kelompok tani Bangkit Merbabu adalah proses budidaya tidak menggunakan pestisida kimia, sedangkan kelemahan adalah berada variabel penerapan dan pengelolaan sistem informasi manajemen belum dijalankan dengan dengan baik dengan nilai total bobot skor rata-rata bernilai 2,993 pada matriks IFE. Faktor eksternal pengembangan usahatani sayuran organik kelompok tani Bangkit Merbabu diperoleh peluang yang berada pada variabel peluang pasar sayuran organik yang luas dalam maupun luar negeri, dan ancaman berada pada variabel kemudahan konsumen 
mendapatkan produk subtitusi dengan nilai bobot skor rata-rata 2,831 pada matriks EFE. Strategi yang dapat diterapkan dalam pengembangan usahatani sayuran organik di kelompok tani Bangkit Merbabu adalah: 1) menjaga dan meningkatkan kualitas hasil sayuran organik; 2) melakukan pengawasan dalam budidaya sampai pasca panen; 3) meningkatkan produksi agar memenuhi permintaan supplier; 4) memperluas area tanam dan menjaga kerja sama antar anggota serta kelompok sub binaan; 5) meningkatkan kerja sama dengan pihak pemerintah maupun swasta dalam bantuan modal maupun pelatihan; 6) meningkatkan pengetahuan petani tentang usahatani sayuran organik; 7) menjaga dan meningkatkan kerja sama dengan supplier yang sudah ada; 8) mempelajari perkembangan teknologi dalam usahatani sayuran organik. Strategi utama berdasarkan matriks QSPM usahatani sayuran organik Bangkit Merbabu adalah menjaga dan meningkatkan kualitas serta produktivitas hasil sayuran organik.

\section{METODE PENELITIAN}

\subsection{Tempat dan Waktu Penelitian}

Lokasi atau tempat penelitian telah dilaksanakan di Kelurahan Kalampangan Kecamatan Sabangau, Kota Palangka Raya. Waktu penelitian ini dilaksanakan selama 3 (tiga) bulan terhitung dari bulan September 2017 sampai dengan November 2017 dengan alokasi kegiatan meliputi persiapan, penyusunan proposal, analisis data sampai dengan penyusunan hasil penelitian dan distribusi dengan data yang dihimpun adalah data tahun 2017.

\subsection{Metode Penentuan Responden}

Data yang digunakan dalam penelitian ini adalah berupa data kualitatif. Menurut Bungin (2003) penelitian kualitatif lebih terfokus pada representasi terhadap fenomena sosial sehingga prosedur sampling yang terpenting adalah bagaimana menentukan informan kunci (key informan) atau situasi sosial tertentu yang sarat informasi sesuai dengan fokus penelitian. Untuk memilih sampel atau informan kunci lebih tepat dilakukan secara purposive sampling (sengaja). Pemilihan sampel tersebut sering disebut dengan judgemental sampling yang didefinisikan sebagai tipe penarikan sampel non probabilitas di mana unit yang hendak diamati atau diteliti/dipilih berdasarkan pertimbangan peneliti dengan anggapan paling bermanfaat dan representatif. Dipertegas oleh Sugiyono (2006) bahwa informan kunci ditentukan dengan pertimbangan tertentu. Pertimbangan tersebut adalah orang tersebut dianggap paling tahu mengenai informasi yang diharapkan atau orang tersebut adalah orang yang berpengaruh sehingga memudahkan peneliti menjelajahi dan menggali informasi dari obyek yang dibutuhkan. Sampel informan merupakan orang yang memberikan informasi yang diperlukan dalam penelitian. Informan terdiri dari dua jenis yaitu informan kunci dan informan biasa. Informan kunci merupakan informan yang mengetahui dan memiliki informasi tentang permasalahan yang sedang diteliti, sedangkan informan biasa merupakan informan yang mengetahui dan berhubungan dengan permasalahan yang diteliti.

\subsection{Jenis dan Sumber Data}

Jenis data yang digunakan dalam penelitian ini meliputi data primer dan data sekunder. Data primer diperoleh melalui pengamatan langsung di lapangan dan melalui wawancara secara langsung dengan petani, penyuluh, dan kelembagaan pendukung yang terkait dengan usahatani sayuran menggunakan daftar pertanyaan (kuesioner) yang mencakup identitas responden, karakteristik usahatani dan variabel-variabel yang menjadi faktor internal dan eksternal pada usahatani sayuran. Data sekunder merupakan data yang diperoleh dari instansi atau lembaga yang terkait antara lain Dinas Pertanian 
Sub Bidang Tanaman Pangan dan Hortikultura, Dinas Perindustrian dan Perdagangan Kota Palangka Raya, Badan Pusat Statistik, Balai Penyuluhan Pertanian, Perikanan dan Kehutanan
(BPPPK) Kalampangan serta berbagai literatur/referensi yang mendukung penelitian ini. Secara singkat jenis dan sumber data yang diperlukan dalam penelitian sebagai berikut:

Tabel 3.1 Jenis dan sumber data yang diperlukan

\begin{tabular}{|c|c|c|}
\hline No. & Jenis Data & Sumber Data \\
\hline 1 & $\begin{array}{l}\text { Data } \\
\text { Primer }\end{array}$ & $\begin{array}{l}\text { a. Petani } \\
\text { b. Penyuluh } \\
\text { c. Kelembagaan pendukung }\end{array}$ \\
\hline 2 & $\begin{array}{l}\text { Data } \\
\text { Sekunder }\end{array}$ & $\begin{array}{l}\text { a. Dinas Pertanian (Sub Bidang Dinas Tanaman Pangan dan } \\
\text { Hortikultura) Kota Palangka Raya. } \\
\text { b. Badan Pusat Statistik (BPS) Kota Palangka Raya } \\
\text { c. Balai Penyuluhan Pertanian, Perikanan dan Kehutanan } \\
\text { (BPPPK) Kalampangan }\end{array}$ \\
\hline
\end{tabular}

\subsection{Metode Pengumpulan Data}

Data yang dikumpulkan dalam penelitian ini berupa data primer dan data sekunder. Data primer dalam bentuk data kualitatif, dimana data dikumpulkan melalui: (1) metode observasi yaitu metode pengumpulan data dengan melakukan pengamatan langsung di daerah penelitian; (2) metode wawancara yaitu metode pengambilan data dengan wawancara/tanya jawab secara langsung dengan responden menggunakan daftar pertanyaan (kuisioner) yang telah dipersiapkan sebelumnya. Kuisioner di sini merupakan alat yang digunakan untuk mendapatkan informasi dari narasumber; (3) metode pencatatan yaitu metode pengumpulan data dengan melakukan pencatatan data dari segala sumber yang berkaitan dengan penelitian; (4) metode studi kepustakaan yaitu metode pengumpulan data yang dilakukan dengan cara mengutip atau mengambil data yang berasal dari sumber yang sudah diolah dari pihak lain. Informasi yang akan digali meliputi, aspek produksi, pemasaran serta kelembagaan pendukung usahatani sayuran. Sedangkan data sekunder diperoleh dari instansi atau lembaga terkait yang masih sesuai dengan tujuan penelitian.

\subsection{Metode Pengolahan dan Analisis Data}

Data dikompilasi dan diolah dalam bentuk tabel dan matriks, kemudian dianalisis. Analisis dimaksudkan untuk membahas dan menjabarkan data yang diperoleh dari hasil penelitian, selanjutnya ditarik suatu kesimpulan sebagai jawaban atas permasalahan penelitian. Dalam penelitian ini analisis yang akan digunakan yaitu analisis deskriptif, dan analisis strategi dengan menggunakan analisis faktor internal atau IFAS (Internal Strategic Factors Analysis Summary), analisis faktor eksternal atau EFAS (External Strategic Factor Analysis Summary), analisis SWOT (matriks SWOT) dan matriks QSPM (Quantitatif Strategic Planning Matriks).

\section{HASIL DAN PEMBAHASAN}

\subsection{Identifikasi Faktor-Faktor Internal dan Eksternal Pengembangan Usahatani Sayuran}

Faktor internal (kekuatan dan kelemahan) dalam usahatani sayuran di Kelurahan Kalampangan dapat dilihat berdasarkan Tabel berikut. 
Tabel 4.1. Kekuatan dan Kelemahan dalam Pengembangan Usahatani Sayuran di Kelurahan Kalampangan,Tahun 2017

\begin{tabular}{|c|c|c|}
\hline $\begin{array}{l}\text { Faktor } \\
\text { Internal }\end{array}$ & Kekuatan & Kelemahan \\
\hline Lahan & $\begin{array}{l}\checkmark \text { Lahan pengembangan cukup } \\
\text { tersedia (S1) }\end{array}$ & $\begin{array}{l}\checkmark \text { Lahan pertanian kurang subur } \\
\text { (lahan gambut) }\end{array}$ \\
\hline Tenaga Kerja & $\begin{array}{l}\checkmark \text { Sebagian besar bekerja sebagai } \\
\text { petani (tidak kekurangan tenaga } \\
\text { kerja) (S2) }\end{array}$ & $\begin{array}{l}\checkmark \text { Sebagian kerja dicurahkan ke usaha } \\
\text { ternak (W2) }\end{array}$ \\
\hline Modal & & $\begin{array}{l}\checkmark \text { Permodalan petani masih kurang } \\
(\mathrm{W} 3)\end{array}$ \\
\hline $\begin{array}{l}\text { Sarana } \\
\text { Produksi }\end{array}$ & $\begin{array}{l}\text { Sarana produksi dan alat } \\
\text { pertanian tersedia secara lokal } \\
(\mathrm{S} 3)\end{array}$ & \\
\hline Pemerintah & & $\begin{array}{l}\checkmark \text { Penyuluhan tidak intensif sehingga } \\
\text { petani tidak mendapatkan teknologi } \\
\text { baru (W4) }\end{array}$ \\
\hline Pemasaran & & $\begin{array}{l}\checkmark \text { Jaraknya dekat dengan pasar namun } \\
\text { harga sayuran masih ditentukan } \\
\text { oleh pedagang pengumpul (W5) }\end{array}$ \\
\hline
\end{tabular}

Sumber: Data Primer yang Diolah, 2017

Faktor internal yang mempengaruhi pengembangan usahatani sayuran terdiri dari kekuatan (Strengths) dan kelemahan (Weaknesses). Faktor kekuatan dalam usahatani sayuran terdiri dari 3 variabel yaitu lahan pengembangan cukup tersedia (S1), sebagian besar bekerja sebagai petani (tidak kekurangan tenaga kerja) (S2), dan sarana produksi dan alat pertanian tersedia secara lokal (S3). Faktor kelemahan dalam usahatani sayuran terdiri dari 5 variabel yaitu lahan pertanian kurang subur (lahan gambut) (W1), sebagian kerja dicurahkan ke usaha ternak (W2), permodalan petani masih kurang (W3), penyuluhan tidak intensif sehingga petani tidak mendapatkan teknologi baru (W4), dan walaupun jaraknya dekat dengan pasar namun harga sayuran masih ditentukan oleh pedagang pengumpul (W5).

Berdasarkan identifikasi faktorfaktor internal tersebut di atas, selanjutnya menyusun matriks IFAS dan melakukan pembobotan serta rating pada masingmasing faktor yang menjadi kekuatan dan kelemahan Tabel 4.2 berikut :

Berdasarkan pada Tabel 4.2 di atas dapat diketahui bahwa hasil bobot dari pendapat responden yang menunjukkan bahwa faktor internal pengembangan usahatani sayuran di Kelurahan Kalampangan memiliki kekuatan utama pada variabel lahan pengembangan cukup tersedia dengan skor 0,88. Dapat diartikan bahwa responden menganggap bahwa faktor tersebut adalah kekuatan yang paling penting, tingginya faktor bobot pada variabel tersebut karena sangat mempengaruhi pendapatan petani. Sedangkan kelemahan utama berada pada variabel lahan pertanian kurang subur (tanah gambut) dengan skor tertinggi 0,40. Hal ini dapat diartikan bahwa petani harus cerdas dalam pengolahan tanah gambut. Berdasarkan hasil akhir matriks IFAS nilai skor rata-rata pada usahatani sayuran di Kelurahan Kalampangan sebesar 4,68. Hal ini dapat dikatakan bahwa faktor internal pengembangan usahatani sayuran berada di atas rata-rata. Jadi dapat disimpulkan bahwa usahatani sayuran di Kelurahan Kalampangan memiliki posisi internal yang kuat, karena dapat menggunakan kekuatan yang ada secara maksimal dalam mengurangi kelemahan yang dimiliki. 
Tabel 4.2. Matriks IFAS Pengembangan Usahatani Sayuran di Kelurahan Kalampangan, Tahun 2017

\begin{tabular}{|c|c|c|c|c|}
\hline No. & Faktor-Faktor Internal & Bobot & Rating & $\begin{array}{l}\text { Nilai Tertimbang } \\
\text { (Bobot x Rating) }\end{array}$ \\
\hline \multicolumn{5}{|c|}{ Kekuatan (Strengths) } \\
\hline 1 & $\begin{array}{l}\text { Lahan pengembangan cukup } \\
\text { tersedia }\end{array}$ & 0,33 & 4 & 1,32 \\
\hline 2 & $\begin{array}{l}\text { Sebagian besar bekerja sebagai } \\
\text { petani (tidak kekurangan } \\
\text { tenaga kerja) }\end{array}$ & 0,34 & 3 & 1,02 \\
\hline \multirow[t]{2}{*}{3} & $\begin{array}{l}\text { Sarana produksi dan alat } \\
\text { pertanian tersedia secara lokal }\end{array}$ & 0,33 & 3 & 0,99 \\
\hline & Total & 1,00 & & 3,33 \\
\hline \multicolumn{5}{|c|}{ Kelemahan (Weaknesses) } \\
\hline 1 & $\begin{array}{l}\text { Lahan pertanian kurang subur } \\
\text { (tanah gambut) }\end{array}$ & 0,20 & 2 & 0,40 \\
\hline & $\begin{array}{l}\text { Sebagian kerja dicurahkan ke } \\
\text { usaha ternak }\end{array}$ & 0,20 & 1 & 0,20 \\
\hline 3 & $\begin{array}{l}\text { Permodalan petani masih } \\
\text { kurang }\end{array}$ & 0,15 & 2 & 0,30 \\
\hline 4 & $\begin{array}{l}\text { Penyuluhan tidak intensif } \\
\text { sehingga petani tidak } \\
\text { mendapatkan teknologi baru }\end{array}$ & 0,21 & 1 & 0,21 \\
\hline \multirow[t]{2}{*}{5} & $\begin{array}{l}\text { Walaupun jaraknya dekat } \\
\text { dengan pasar namun harga } \\
\text { sayuran masih ditentukan oleh } \\
\text { pedagang pengumpul }\end{array}$ & 0,24 & 1 & 0,24 \\
\hline & Total & 1,00 & & 1,35 \\
\hline & Total Matriks IFAS & & & 4,68 \\
\hline
\end{tabular}

Sumber: Data Primer yang Diolah, 2017

Faktor eksternal (peluang dan ancaman)

Kalampangan dapat dilihat berdasarkan dalam usahatani sayuran di Kelurahan berikut

Tabel 4.3. Faktor Eksternal (Peluang dan Ancaman) dalam Pengembangan Usahatani Sayuran di Kelurahan Kalampangan, Tahun 2017

\begin{tabular}{llll}
\hline \multicolumn{1}{c}{ Faktor Eksternal } & & \multicolumn{1}{c}{ Peluang } & \multicolumn{1}{c}{ Ancaman } \\
\hline Ekonomi & $\checkmark$ & $\begin{array}{l}\text { Permintaan pasar meningkat (O1) } \\
\text { Petani menjual hasil pertaniannya } \\
\text { kepada pedagang pengumpul, jarak } \\
\text { pesaing terlalu jauh ke pasar (O2) }\end{array}$ & $\begin{array}{l}\checkmark \text { Adanya pesaing tetapi } \\
\text { sedikit baik itu dari } \\
\text { impor atau dari luar } \\
\text { kota (T1) }\end{array}$ \\
\hline Transportasi & $\checkmark$ & $\begin{array}{l}\text { Jarak lokasi pesaing dengan pasar } \\
\text { sayuran lebih jauh (O3) }\end{array}$ & \\
\hline $\begin{array}{l}\text { Tempat } \\
\text { Usaha/Lahan }\end{array}$ & & & $\checkmark$ \\
\hline Sosial dan Budaya & & & $\begin{array}{l}\text { Lahan pesaing lebih } \\
\text { subur (T2) }\end{array}$ \\
& & & $\begin{array}{l}\text { Perubahan cuaca dan } \\
\text { perkembangan OPT } \\
\text { (T3) }\end{array}$ \\
\hline
\end{tabular}

Sumber: Data Primer yang Diolah, 2017 
Faktor eksternal pengembangan usahatani sayuran terdiri dari peluang (opportunities) dan ancaman (threats). Faktor peluang dalam usahatani sayuran terdiri dari tiga variabel yaitu permintaan pasar meningkat (O1), jarak lokasi pesaing dengan pasar sayuran lebih jauh (O2), dan karena jarak pesaing terlalu jauh ke pasar maka petani menjual hasil pertaniannya kepada pedagang pengumpul (O3). Faktor ancaman dalam usahatani sayuran terdiri dari 3 variabel yaitu adanya pesaing lokal dan luar daerah tetapi sedikit (T1), lahan pesaing lebih subur (T2), dan adanya perubahan cuaca serta perkembangan OPT (T3).

Berdasarkan identifikasi faktorfaktor eksternal tersebut di atas, selanjutnya menyusun matriks EFAS dan melakukan pembobotan serta rating pada masing-masing faktor yang menjadi peluang dan ancaman diperoleh Tabel 4.4. berikut.

Tabel 4.4. Matriks EFAS dalam Pengembangan Usahatani Sayuran di Kelurahan Kalampangan, Tahun 2017

\begin{tabular}{|c|c|c|c|c|}
\hline No. & Faktor-Faktor Eksternal & Bobot & Rating & $\begin{array}{l}\text { Nilai Tertimbang } \\
\text { (Bobot x Rating) }\end{array}$ \\
\hline \multicolumn{5}{|c|}{ Peluang (Opportunities) } \\
\hline \multirow{3}{*}{\multicolumn{2}{|c|}{$\begin{array}{l}1 \text { Permintaan pasar meningkat } \\
2 \text { Jarak lokasi pesaing dengan pasar } \\
\text { sayuran lebih jauh } \\
3 \text { Karena jarak pesaing terlalu jauh ke } \\
\text { pasar maka petani menjual hasil } \\
\text { pertaniannya kepada pedagang } \\
\text { pengumpul }\end{array}$}} & 0,33 & 4 & 1,32 \\
\hline & & 0,32 & 2 & 0,64 \\
\hline & & 0,35 & 3 & 1,05 \\
\hline \multicolumn{2}{|r|}{ Total } & 1,00 & & 3,01 \\
\hline \multicolumn{5}{|c|}{ Ancaman (Threats) } \\
\hline & $\begin{array}{l}\text { Adanya pesaing tetapi sedikit baik } \\
\text { itu dari impor atau dari luar kota }\end{array}$ & 0,38 & 2 & 0,76 \\
\hline & \multirow{2}{*}{$\begin{array}{l}\text { Lahan pesaing lebih subur } \\
\text { Adanya perubahan cuaca serta } \\
\text { perkembangan OPT }\end{array}$} & 0,32 & 1 & 0,32 \\
\hline & & 0,30 & 1 & \multirow{2}{*}{$\begin{array}{l}0,30 \\
1,38\end{array}$} \\
\hline \multicolumn{2}{|r|}{ Total } & 1,00 & & \\
\hline
\end{tabular}

Sumber: Data Primer yang Diolah, 2017

Berdasarkan pada Tabel 4.4 dapat diketahui bahwa dalam pengembangan usahatani sayuran di Kelurahan Kalampangan memiliki peluang faktor strategis eksternal yang paling utama berada pada variabel trend permintaan pasar yang meningkat dengan skor ratarata sebesar 1,32. Ancaman utama pada pengembangan usahatani ini berada pada variabel ancaman adanya pesaing lokal dan luar daerah tetapi sedikit dengan skor sebesar 0,76. Hal ini menyebabkan produksi sayuran di Kelurahan Kalampangan harus mampu bersaing. Berdasarkan nilai matriks EFAS di atas menunjukan nilai skror rata-rata faktor eksternal pengembangan usahatani sayuran di Kelurahan Kalampangan sebesar 4,39. Seperti yang diungkapkan oleh David (2006) jika total skor pembobotan di bawah 2,5 maka perusahaan tersebut memiliki faktor strategis ekternal yang sangat lemah. Sedangkan pada usahatani sayuran di Kelurahan Kalampangan di atas 
rata-rata 2,5 jadi dapat disimpulkan bahwa upaya pengembangan usahatani sayuran di Kelurahan Kalampangan kuat karena mampu memanfaatkan peluang untuk mengurangi ancaman yang ada.

Penentuan hasil analisis faktor lingkungan internal dan eksternal berupa total skor perlu dilakukan dalam mengevaluasi strategi yang dilaksanakan.
Hasil dari analisis didapat dari mengurangkan jumlah nilai tertimbang (bobot $\times$ rating) pada peluang dengan jumlah nilai tertimbang (bobot $\times$ rating) pada ancaman sehingga mendapatkan nilai koordinat. Begitu juga dengan jumlah nilai tertimbang (bobot $\times$ rating) pada kekuatan dikurangi jumlah bobot pada kelemahan sehingga mendapatkan nilai koordinatnya.

Tabel 4.5. Hasil Skoring Faktor Internal dan Eksternal dalam Pengembangan Usahatani Sayuran di Kelurahan Kalampangan, Tahun 2017

\begin{tabular}{|c|c|c|}
\hline Kriteria & Skor & Koordinat \\
\hline \multicolumn{3}{|l|}{ Faktor Internal } \\
\hline Kekuatan & 3,33 & 1,98 \\
\hline Kelemahan & 1,35 & \\
\hline \multicolumn{3}{|l|}{ Faktor Eksternal } \\
\hline Peluang & 3,01 & 1,63 \\
\hline Ancaman & 1,38 & \\
\hline
\end{tabular}

Sumber: Data Primer yang Diolah, 2017

Kondisi Internal : Kekuatan lebih besar daripada Kelemahan $(1,98)$

Kondisi Eksternal : Peluang lebih besar daripada ancaman $(1,63)$

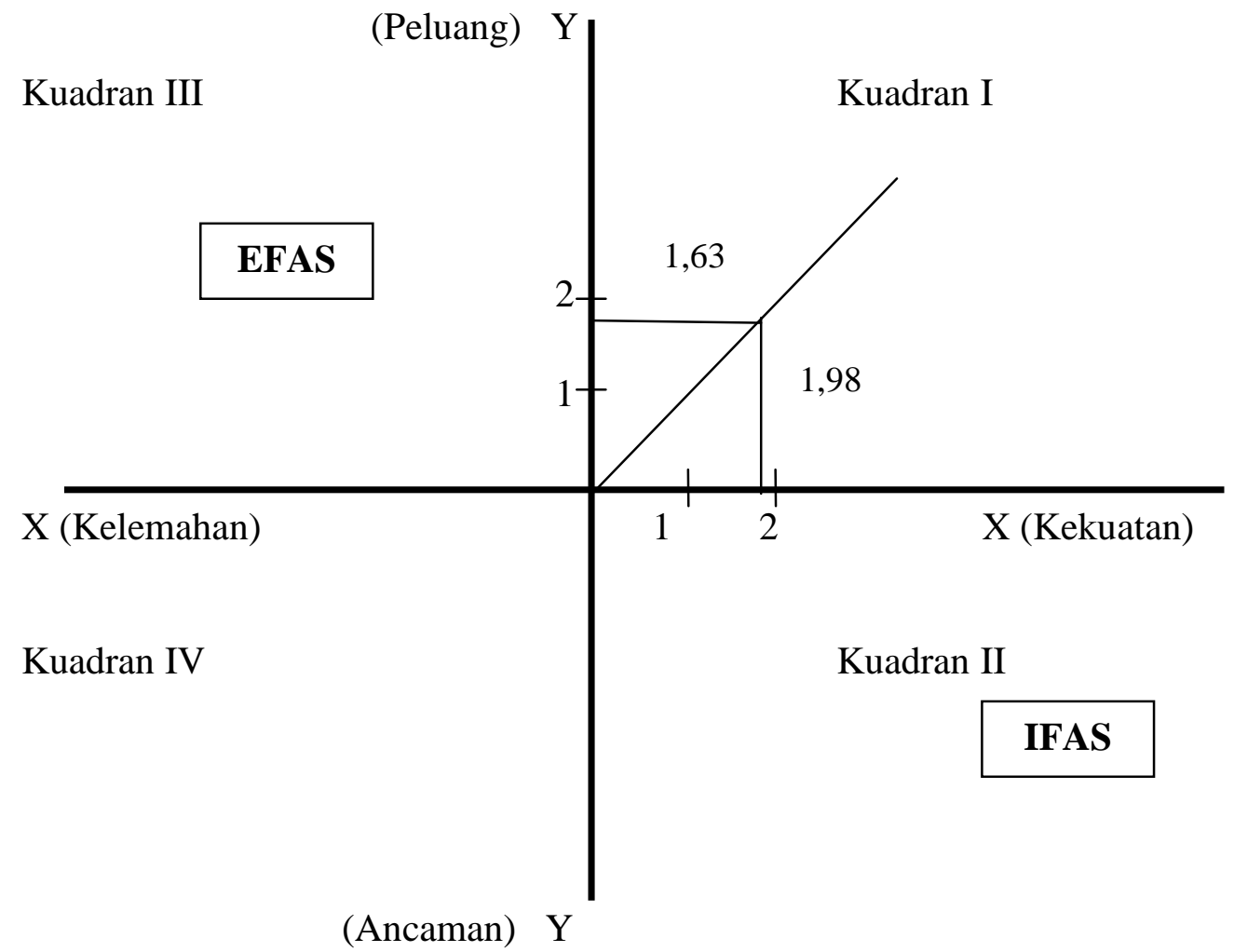

Gambar 4.1. Posisi Kuadran dalam Diagram SWOT 
Nilai sumbu $\mathrm{X}=\mathrm{S}+(-\mathrm{W})$

$$
\begin{aligned}
& =3,33+(-1,35) \\
& =1,98
\end{aligned}
$$

Berdasarkan gambar 4.1 di atas posisi pengembangan usahatani sayuran di Kelurahan Kalampangan terletak pada kuadran satu (mendukung strategi agresif). Titik koordinat menempati posisi pada kuadran satu yaitu mendukung strategi agresif yang berarti situasi yang begitu menguntungkan. Usahatani sayuran di Kelurahan Kalampangan memiliki peluang dan kekuatan sehingga dapat memanfaatkan peluang yang ada. Strategi yang harus diterapkan dalam kondisi ini adalah mendukung kebijakan pertumbuhan yang agresif (growth oriented strategy).

\subsection{Perumusan Strategi Pengembangan Usahatani Sayuran}

Setelah mengidentifikasi faktorfaktor eksternal dan internal yang menjadi peluang, ancaman serta kekuatan dan kelemahan dalam pengembangan usahatani sayuran ini, maka dengan menggunakan analisis matriks SWOT diperoleh beberapa alternatif strategi yang dapat dipertimbangkan guna pengembangan usahatani sayuran. Matriks SWOT menggambarkan secara jelas bagaimana peluang dan ancaman eksternal dapat dipadukan dengan kekuatan dan kelemahan internal sehingga dihasilkan rumusan strategi pengembangan usahatani. Matriks ini menghasilkan empat sel kemungkinan alternatif strategi, yaitu strategi S-O, strategi W-O, strategi W-T, dan strategi S-T. Teknik mendapatkan rumusan alternatif strategi pengembangan sayuran di wilayah Kelurahan Kalampangan dengan metode analisis SWOT, perlu dilakukan penggabungan indikator internal (kekuatan dan kelemahan) dan eksternal (peluang dan ancaman). Analisis matriks SWOT dalam perumusan strategi alternatif dapat dilihat pada Tabel 4.6. di bawah ini.

Dari Tabel 4.6 di atas dapat diperinci 4 (empat) strategi yakni Strategi S-O (Strength-Opportunity), Strategi W-O

$$
\text { Nilai sumbu } \begin{aligned}
\mathrm{Y} & =\mathrm{O}+(-\mathrm{T}) \\
& =3,01+(-1,38) \\
& =1,63
\end{aligned}
$$

(Weakness-Opportunities), Strategi S-T (Strength-Threat), dan Strategi W-T (Weakness-Threat) sebagai berikut :

$$
\text { Strategi S-O (Strength- }
$$

Opportunity) atau strategi kekuatanpeluang adalah strategi yang disusun dengan cara menggunakan semua kekuatan untuk merebut peluang. Alternatif strategi S-O yang dapat dirumuskan adalah:

a) Mengoptimalkan potensi lahan yang dimiliki melalui pembukaan akses jalan ke lahan usahatani sayuran (S1, S2,O1,O2).

b) Memperluas areal tanaman sayuran (S1, S2, S3, O1, O3).

Strategi W-O (WeaknessOpportunities) atau strategi kelemahanpeluang adalah strategi yang disusun dengan cara meminimalkan kelemahan untuk memanfaatkan peluang yang ada. Alternatif strategi W-O yang dapat dirumuskan adalah:

a) Mengikuti perkembangan teknologi dalam usahatani sayuran khususnya sayuran organik (W1, W2, O1)

b) Mengembangkan usaha dengan pemanfaatan bantuan modal (W1, W2, W3,O1, O2, O3)

Strategi S-T (Strength-Threat) atau strategi kekuatan-ancaman adalah strategi yang disusun dengan cara menggunakan semua kekuatan untuk mengatasi ancaman. Strategi yang dapat dirumuskan adalah:

a) Meningkatkan produksi dan mutu hasil panen (S1, S2,S3,T1,T2,T3).

Strategi W-T (Weakness-Threat) atau strategi kelemahan-ancaman adalah strategi yang disusun dengan cara meminimalkan kelemahan untuk menghindari ancaman. Alternatif strategi S-T yang dapat dirumuskan adalah:

a) Mengupayakan lahan gambut layak dijadikan menjadi lahan pertanian (W1, W2,T1,T2).

b) Menekan adanya biaya seminimal mungkin (W3, W4, W5,T1, T3) 
Tabel 4.6. Penentuan Strategi Pengembangan Usahatani Sayuran di kelurahan Kalampangan dengan menggunakan Matriks SWOT

\begin{tabular}{|c|c|c|}
\hline & Strenght (S) & Weakness (W) \\
\hline EFAS & $\begin{array}{l}\text { 1. Lahan pengembangan } \\
\text { cukup tersedia } \\
\text { 2. Sebagian besar bekerja } \\
\text { sebagai petani (tidak } \\
\text { kekurangan tenaga } \\
\text { kerja) } \\
\text { 3. Sarana produksi dan alat } \\
\text { pertanian tersedia secara } \\
\text { lokal }\end{array}$ & $\begin{array}{l}\text { 1. Lahan pertanian kurang } \\
\text { subur (lahan gambut) } \\
\text { 2. Sebagian kerja dicurahkan } \\
\text { ke usaha ternak } \\
\text { 3. Permodalan petani masih } \\
\text { kurang } \\
\text { 4. Penyuluhan tidak intensif } \\
\text { sehingga petani kurang } \\
\text { pengetahuan teknologi baru } \\
\text { 5. Walaupun jaraknya dekat } \\
\text { dengan pasar namun harga } \\
\text { sayuran masih ditentukan } \\
\text { oleh pedagang pengumpul }\end{array}$ \\
\hline Opportunities (O) & & \\
\hline $\begin{array}{l}\text { 1. Permintaan pasar } \\
\text { meningkat } \\
\text { 2. Jarak lokasi pesaing } \\
\text { dengan pasar sayuran } \\
\text { lebih jauh } \\
\text { 3. Karena jarak pesaing } \\
\text { terlalu jauh ke pasar maka } \\
\text { petani menjual hasil } \\
\text { pertaniannya kepada } \\
\text { pedagang pengumpul }\end{array}$ & $\begin{array}{l}\text { 1. Mengoptimalkan potensi } \\
\text { lahan yang dimiliki } \\
\text { melalui pembukaan } \\
\text { akses jalan ke lahan } \\
\text { usahatani sayuran (S1, } \\
\text { S2,O1,O2) } \\
\text { 2. Memperluas area tanam } \\
\text { sayuran (S1, S2, S3,O1, } \\
\text { O3) }\end{array}$ & $\begin{array}{l}\text { 1. Mempelajari } \\
\text { perkembangan teknologi } \\
\text { dalam usahatani sayuran } \\
\text { khususnya sayuran } \\
\text { oranik (W1, W2,O1) } \\
\text { 2. Mengembangkan usaha } \\
\text { dengan pemanfaatan } \\
\text { bantuan modal (W1, } \\
\text { W2, W3,O1, O2, O3) }\end{array}$ \\
\hline
\end{tabular}

1. Adanya pesaing tetapi sedikit baik itu dari impor atau dari luar kota

2. Lahan pesaing lebih subur

3. Adanya perubahan cuaca serta perkembangan OPT
1. Mengupayakan lahan gambut layak dijadikan menjadi lahan pertanian (W1, W2,T1,T2)

2. Menekan adanya biaya seminimal mungkin (W3, W4, W5,T1, T3)

Sumber: Data Primer yang Diolah, 2017

\subsection{Penentuan Prioritas Strategi Pengembangan Usahatani Sayuran}

Tahap pemilihan strategi merupakan tahap ketiga dari proses manajemen strategi. Berdasarkan hasil analisis QSPM, ditunjukkan pada Tabel 4.7 diperoleh gambaran bahwa nilai TAS (Total Attractives Score) dari strategi pengembangan usahatani sayuran yang menunjukkan nilai tertinggi sampai terendah adalah sebagai berikut: 
Tabel 4.7. Penentuan Prioritas Strategi Pengembangan Usahatani Sayuran dengan Matriks QSPM

\begin{tabular}{|c|c|c|c|c|c|c|c|}
\hline \multirow{2}{*}{ Faktor-Faktor Kunci } & \multirow{2}{*}{ Bobot } & \multicolumn{2}{|c|}{ Strategi I } & \multicolumn{2}{|c|}{ Strategi 2} & \multicolumn{2}{|c|}{ Strategi 3} \\
\hline & & $\mathrm{AS}$ & TAS & $\mathrm{AS}$ & TAS & $\mathrm{AS}$ & TAS \\
\hline \multicolumn{8}{|l|}{ Internal : } \\
\hline $\begin{array}{l}\text { Lahan pengembangan cukup } \\
\text { tersedia }\end{array}$ & 0,33 & 3 & 0,99 & 2 & 0,66 & 3 & 0,99 \\
\hline $\begin{array}{l}\text { Sebagian besar bekerja sebagai } \\
\text { petani (tidak kekurangan tenaga } \\
\text { kerja) }\end{array}$ & 0,34 & 2 & 0,68 & 3 & 1,02 & 4 & 1,36 \\
\hline $\begin{array}{l}\text { Sarana produksi dan alat } \\
\text { pertanian tersedia secara lokal }\end{array}$ & 0,33 & 4 & 1,32 & 3 & 0,99 & 4 & 1,32 \\
\hline $\begin{array}{l}\text { Lahan pertanian kurang subur } \\
\text { (lahan gambut) }\end{array}$ & 0,20 & 1 & 0,20 & 2 & 0,40 & 4 & 0,80 \\
\hline $\begin{array}{l}\text { Sebagian kerja dicurahkan ke } \\
\text { usaha ternak }\end{array}$ & 0,20 & 3 & 0,60 & 3 & 0,60 & 4 & 0,80 \\
\hline Permodalan petani masih kurang & 0,15 & 1 & 0,15 & 2 & 0,30 & 1 & 0,15 \\
\hline $\begin{array}{l}\text { Penyuluhan tidak intensif } \\
\text { sehingga petani tidak } \\
\text { mendapatkan teknologi baru }\end{array}$ & 0,21 & 2 & 0,42 & 3 & 0,63 & 3 & 0,63 \\
\hline $\begin{array}{l}\text { Jarak dengan pasar dekat namun } \\
\text { harga sayuran masih ditentukan } \\
\text { oleh pedagang pengumpul }\end{array}$ & 0,24 & 2 & 0,48 & 3 & 0,72 & 2 & 0,48 \\
\hline \multicolumn{8}{|l|}{ Eksternal } \\
\hline Permintaan pasar meningkat & 0,33 & 3 & 0,99 & 2 & 0,66 & 3 & 0,99 \\
\hline $\begin{array}{l}\text { Jarak lokasi pesaing lokal dengan } \\
\text { pasar sayuran lebih jauh }\end{array}$ & 0,32 & 3 & 0,96 & 4 & 1,28 & 1 & 0,32 \\
\hline $\begin{array}{l}\text { Bersaing dengan pedagang } \\
\text { pengumpul sayuran (luar daerah) }\end{array}$ & 0,35 & 3 & 1,05 & 2 & 0,70 & 2 & 0,70 \\
\hline $\begin{array}{l}\text { Adanya pesaing tetapi sedikit baik } \\
\text { itu dari impor atau dari luar kota }\end{array}$ & 0,38 & 1 & 0,38 & 2 & 0,76 & 2 & 0,76 \\
\hline Lahan pesaing lebih subur & 0,32 & 2 & 0,64 & 2 & 0,64 & 1 & 0,32 \\
\hline $\begin{array}{l}\text { Adanya perubahan cuaca serta } \\
\text { perkembangan OPT }\end{array}$ & 0,30 & 2 & 0,60 & 1 & 0,30 & 2 & 0,60 \\
\hline Jumlah Total Nilai Daya Tarik & & & 9,46 & & 9,66 & & 10,22 \\
\hline
\end{tabular}

Keterangan: AS : Attractives Score/Nilai daya tarik

TAS : Total Attractives Score/Total nilai daya tarik
$1=$ Tidak menarik
$3=$ Wajar menarik
$2=$ Agak menarik
$4=$ Sangat menarik

Sumber: Data Primer yang Diolah, 2017

Dari hasil analisis matriks SWOT telah diperoleh delapan alternative strategi yang bisa diterapkan untuk pengembangan agribisnis sayuran di Kelurahan Kalampangan. Untuk menentukan strategi prioritas yang paling tepat dan utama maka dilakukan analisis matriks QSPM untuk pengambilan keputusan. Matriks QSPM memberikan gambaran kelebihankelebihan relatif dari masing-masing strategi yang selanjutnya memberikan dasar objektif untuk dapat memilih salah 
satu atau beberapa strategi spesifik yang menjadi pilihan. Langkah selanjutnya adalah mencari alternatif strategi yang dapat diimplementasikan sehingga terpilih tiga strategi, yaitu :

a) Sebagian besar bekerja sebagai petani (tidak kekurangan tenaga kerja) (1,36). Dalam pengembangan usahatani sayuran di Kelurahan Kalampangan sama sekali tidak kekurangan tenaga kerja karena sebagian besar bekerja sebagai petani. Sehingga dalam upaya untuk mempertahankan dan meningkatkan produksi serta kualitas sayuran ditujukan agar sayuran di Kelurahan Kalampangan dapat bertahan dari persaingan dengan sayuran dari daerah lain dan juga untuk memenuhi tuntutan pembeli terhadap permintaan yang terus meningkat. Petani bekerja untuk lahannya masing-masing dengan kata lain tenaga kerja berasal dari keluarga, kebanyakan di Kelurahan Kalampangan petani mengambil semua anggota keluarga untuk saling membantu dalam usahatani sayuran mereka

b) Sarana produksi dan alat pertanian tersedia secara lokal $(1,32)$. Strategi ini didasarkan pada kondisi usahatani di Kelurahan Kalampangan dimana mayoritas penduduknya bekerja sebagai petani sayuran. Dengan demikian tersedianya sarana produksi dan alat pertanian secara lokal adalah sesuatu hal yang sangat menguntungkan bagi petani di mana mereka tidak perlu buangbuang waktu dan tenaga hanya untuk mendapatkan apa yang dibutuhkan. Dalam penerapan usahatani yang baik, petani harus memiliki kualitas SDM yang tinggi dalam penerapan teknik budidaya sayuran yang berjangka panjang. Selain itu, dengan keberadaan kios- kios pertanian setempat mampu mempermudah petani dalam memperoleh alat-alat pertanian sehingga dengan alat-alat tersebut para petani merasa cukup terbantu dan bisa melakukan hal lainnya yang berhubungan dengan usahatani sayuran.

c) Jarak lokasi pesaing dengan pasar sayuran lebih jauh $(1,28)$. Penerapan strategi ini penting peranannya dalam mendorong perkembangan usahatani sayuran. Petani memanfaatkan potensi ini di mana jarak lokasi pesaing dengan pasar sayuran lebih jauh yang sangat sesuai dalam pengembangan usahatani sayuran. Karena jarak distribusi pesaing lebih jauh dibandingkan dengan Kelurahan Kalampangan akan sangat berpengaruh terhadap kualitas sayuran dari panen hingga sampai ke pasar. Karena jarak lokasi pesaing dengan pasar sayuran lebih jauh, maka akan semakin banyak juga biaya yang dikeluarkan baik itu biaya transportasi, biaya makan maupun akan lebih banyak tenaga dan waktu yang dicurahkan untuk hal tersebut. Selainitu, produk pertanian yang rentan mudah rusak, busuk akan sangat berpengaruh terhadap jarak lokasi dengan pasar.

\section{PENUTUP}

\subsection{Kesimpulan}

Berdasarkan hasil penelitian mengenai strategi pengembangan usahatani sayuran di Kelurahan Kalampangan dapat diperoleh beberapa kesimpulan sebagai berikut:

1. Faktor-faktor internal (kekuatan dan kelemahan) dan eksternal (peluang dan ancaman) pengembangan usahatani sayuran di Kelurahan Kalampangan yaitu kekuatan utama berada pada variabel lahan pengembangan cukup tersedia dengan 
skor 1,32. Kelemahan utamanya adalah pada variabel lahan pertanian kurang subur (tanah gambut) dengan skor tertinggi 0,40. Peluang utama berada pada variabel permintaan pasar meningkat dengan skor rata-rata sebesar 1,32. Sedangkan ancaman utama adalah pada variabel adanya pesaing lokal dan luar kota tetapi sedikit dengan skor sebesar 0,76.

2. Analisis strategi melalui matriks SWOT menghasilkan tujuh alternatif strategi. Alternatif strategi yang dapat diterapkan dalam upaya pengembangan usahatani sayuran di Kelurahan Kalampangan adalah strategi (SO) yaitu: mengoptimalkan potensi lahan yang dimiliki melalui pembukaan akses jalan ke lahan usahatani sayuran, dan memperluas area tanam sayuran; strategi (WO) yaitu mempelajari perkembangan teknologi dalam usahatani sayuran khususnya sayuran oranik, dan mengembangkan usaha dengan pemanfaatan bantuan modal; strategi (ST) yaitu meningkatkan produksi dan mutu hasil panen; strategi (WT) yaitu mengupayakan lahan gambut layak dijadikan menjadi lahan pertanian dan menekan adanya biaya seminimal mungkin.

3. Strategi prioritas yang dapat diterapkan dalam upaya pengembangan usahatani sayuran di Kelurahan Kalampangan berdasarkan QSPM yaitu: sarana produksi dan alat pertanian tersedia secara lokal, jarak lokasi pesaing dengan pasar sayuran lebih jauh, dan tidak kekurangan tenaga kerja.

\subsection{Saran}

Berdasarkan beberapa kesimpulan di atas maka disarankan bagi:

1. Petani agar menerapkan teknik budidaya sayuran yang baik untuk meningkatkan produksi, kualitas dan mutu hasil panen serta pendapatan petani. Petani sayuran juga sebaiknya mengembangkan usahatani sayurannya dengan meminimalkan biaya produksi dan memanfaatkan bantuan modal yang diberikan oleh pemerintah.

2. Pemerintah khususnya di Kelurahan Kalampangan perlu memberikan pendidikan dan pelatihan lebih rutin terutama dalam mengelola keuangan petani, penetapan harga pokok produksi dan pengelolaan pasca panen agar tercipta pengelolaan usahatani yang handal sehingga akan menghasilkan usahatani sayuran yang mempunyai daya saing tinggi. Perlu pula dilakukan koordinasi antar instansi terkait dalam pengembangan usahatani sayuran ini agar program yang dilaksanakan dapat berjalan lebih efektif dan efisien. Pemerintah hendaknya dapat merangsang munculnya organisasi-organisasi di tingkat petani sekaligus memfasilitasinya. Organisasi yang muncul dari kesadaran petani akan lebih dapat menampung aspirasi petani.

\section{DAFTAR PUSTAKA}

Astawan, M. 2007. Sehat Optimal dengan Sayur dan Buah. http://www.kompas.com/verl/keseh atan/07/12/16.htm (Diakses 04 Juli 2017).

Bungin, B. 2003. Analisis Data Penelitian Kualitatif. Pemahaman Filisofis dan Metodologis ke arah Penguasaan Model Aplikasi. Raja Grafindo Persada. Jakarta.

David, F.R. 2004. Manajemen Strategis: Konsep-konsep, Alih Bahasa: Kresno Santoso. PT Indeks Kelompok Gramedia. Jakarta.

Firmansyah, B. Y. 2016. Strategi Pengembangan Usahatani Sayuran Organik Kelompok Tani Bangkit 
Merbabu di Kabupaten Semarang Provinsi Jawa Tengah. Skripsi. Universitas Kristen Satya Wacana. Salatiga.

Mintzberg H. 1993. Stucture in Five : Designing Effective Organizations. Prentice Hall, Inc, A Simon \& Schuster Company. Englewood Cliff. New Jersey 07632. Amerika Serikat (US).
Rangkuti, F. 2009. Analisis SWOT Teknik Membedah Kasus Bisnis.

Gramedia Pustaka Utama. Jakarta.

Setyati, H. S. 1989. Dasar-dasar Hortikultura. Jurusan Budidaya Pertanian, IPB. Bogor.

Soekartawi. 2000. Pembangunan Pertanian. Rajawali press: Jakarta.

Sugiyono.2006. Metode Penelitian Kualitatif dan R \& D. Alfabeta. Bandung. 